\title{
POLICY RULES UNTUK PENGENDALIAN INFLASI SECARA FORWARD LOOKING
}

\author{
Akhis R. Hutabarat, Reza Anglingkusumo, \\ Fadjar Majardi, Rizki E. Wimanda*)
}

\section{Pendahuluan}

elaras dengan pesan inti UU No.23/1999 tentang kewajiban Bank Indonesia untuk menjaga stabilitas internal dan eksternal nilai Rupiah, maka stabilisasi laju inflasi dalam jangka panjang merupakan agenda utama yang perlu diupayakan secara sungguh-sungguh pencapaiannya. Pesan implisit undang-undang agar Bank Indonesia melalui kebijakan moneternya mencapai sasaran laju inflasi yang rendah dan stabil, bertolak dari argumen mengenai pentingnya stabilisasi laju inflasi bagi perekonomian secara makro. Sebagaimana telah banyak dikemukakan oleh para akademisi dan praktisi, manfaat stabilisasi inflasi pada intinya berkisar pada biaya yang harus ditanggung oleh perekonomian jika laju inflasi berada pada level yang tinggi dan tidak stabil.

Namun demikian, pencapaian laju inflasi yang rendah dan stabil melalui kebijakan moneter bukanlah hal yang sederhana. Adanya ketidakpastian yang tinggi mengenai jenis dan besarnya shocks yang akan dihadapi di masa datang, serta ketidakpastian mengenai mekanisme transmisi dan parameter yang membentuknya, menjadi sumber permasalahan utama dalam perumusan kebijakan moneter ${ }^{1}$. Untuk kasus Indonesia, tingkat ketidakpastian ini menjadi isu yang penting karena hubungan antara uang beredar dan sasaran akhir kebijakan moneter semakin melemah, sehingga efektifitas Bank Indonesia dalam mengendalikan jumlah uang beredar sebagai sasaran antara kebijakan moneter diyakini semakin berkurang ${ }^{2}$. Isu lainnya yang mengurangi kemampuan kebijakan moneter adalah adanya efek tunda (lag) kebijakan moneter dan ketidakpastian pengukuran kesenjangan output yang sifatnya unobservable.

*) Akhis R Hutabarat : Peneliti Ekonomi Yunior di Bagian Studi Sektor Rill, Direktorat Riset Ekonomi dan Kebijakan Moneter, Bank Indonesia

*) Reza Angling Kusumo, fadjar Majardi, Rizki E. Wimanda : Asisten Peneliti Ekonomi di Bagian Studi Sektor Rill, Direktorat Riset Ekonomi dan Kebijakan Moneter, Bank Indonesia

1 “....(the tasks of monetary policy are) long range weather forecasting in a stochastic world of time varying lags and coefficients" Eric Schaling (Bank of England, 1999)

2 “......relationship between monetary aggregates and ultimate targets tend to be weaker and "blurry"”. Achjar Iljas, BIS Special Meeting (1997)

“......seakan-akan terdapat arus kuat di balik perkembangan M0 yang tidak terjangkau oleh instrumen-instrumen OPT kita”, Boediono, (1998) 
Merujuk pada permasalahan yang sama yang dihadapi oleh bank sentral negara lain, maka pengalaman BoE, BoC, RBNZ, RBA, dan Swedish Riksbank menunjukkan bahwa untuk mengatasi permasalahan-permasalahan tersebut diperlukan suatu framework kebijakan moneter yang forward-looking dalam mengendalikan inflasi.

Framework tersebut bercirikan (1) proyeksi inflasi dan tingkat kesenjangan output yang sustainable sebagai sasaran antara (inflation forecast targeting), dan (2) kebijakan moneter yang dilakukan secara "constrained discretionary" dengan bantuan forward looking policy rule, untuk meminimisasi gejolak kesenjangan output dan inflasi ke depan. Constrained discretion adalah perumusan kebijakan moneter dengan mempertimbangkan usulan-usulan dari hasil perhitungan mekanistis melalui policy rule, yaitu suatu mekanisme feedback yang menghubungkan suku bunga jangka pendek sebagai variabel kebijakan bank sentral dengan sasaran akhir kebijakan moneter, misalnya inflasi. Dengan adanya mekanisme feedback ini, maka variabel kebijakan akan ditentukan secara endogen dalam model ekonomi makro simultan, sehingga diperoleh rekomendasi path variabel kebijakan secara mekanistis. Selanjutnya hasil dari perhitungan mekanistis tersebut dijadikan guidance untuk discretionary policy oleh Dewan Gubernur.

Penelitian ini bertujuan mengetahui jenis forward looking policy rule yang sesuai untuk kondisi perekonomian Indonesia dan parameter policy rule yang akan digunakan dalam fungsi reaksi kebijakan moneter pada small model macroeconomic Bank Indonesia. Berdasarkan hasil penelitian mengenai policy rule tersebut, informasi utama yang ingin diperoleh adalah path optimal variable kebijakan suku bunga jangka pendek, dalam hal ini suku bunga Sertifikat Bank Indonesia (SBI 1 bulan), yang harus diatur dalam rangka stabilisasi inflasi.

\section{Konsep Dasar}

Kebijakan bank sentral dalam mempengaruhi besaran-besaran moneternya, termasuk di dalamnya laju inflasi, dapat dikategorikan dalam dua kelompok, yaitu rule dan discretion $^{3}$. Sementara itu, oleh beberapa ekonom rezim Inflation Targeting dikategorikan sebagai constrained discretion karena dalam penentuan besaran instrument yang akan digunakan, bank sentral biasanya menggabungkan antara policy rule dengan judgment dari para pengambil kebijakan ${ }^{4}$.

3 Kebijakan yang dilakukan secara discretion adalah jika pembuat kebijakan dapat bebas untuk melakukan penyesuaian secara case-by-case dan memilih kebijakan yang sesuai. Sedangkan kebijakan yang dilakukan secara rule adalah jika pembuat kebijakan mengumumkan sebelumnya bagaimana suatu kebijakan akan merespon dari beberapa situasi yang terjadi dan komit untuk mengikuti aturan yang ditetapkan.

4 Judgement ini digunakan untuk menangkap informasi-informasi penting yang tidak dapat ditangkap oleh model. 
Pembentukan policy rule dalam kerangka Inflation Targeting (IT) biasanya dibangun dengan 2 cara, yaitu dynamic optimization dan stochastic simulation. Dalam metode yang pertama, policy rule dihasilkan dari meminimisasi Loss Function dengan constraint (subject to) model makroekonomi.

Bentuk umum dari Social Loss Function bank sentral dimodelkan dengan fungsi kuadratik dari deviasi inflasi dari targetnya, kesenjangan output, dan perubahan suku bunga nominal jangka pendek.

$$
\mathrm{L}_{\mathrm{t}}=\gamma\left(\pi_{\mathrm{t}}-\pi^{*}\right)^{2}+\lambda\left(\mathrm{y}_{\mathrm{t}}-\mathrm{y}^{*}\right)^{2}+\mathrm{v}\left(\mathrm{i}_{\mathrm{t}}-\mathrm{i}_{\mathrm{t}-1}\right)^{2}
$$

dimana $\pi_{\mathrm{t}}$ adalah inflasi pada periode $\mathrm{t}, \pi^{*}$ adalah target inflasi, $\mathrm{y}_{\mathrm{t}}$ adalah output aktual, $\mathrm{y}^{*}$ adalah output potential, $i_{t}$ adalah suku bunga nominal pada periode $t$, dan $\{\gamma, \lambda, v\}$ adalah bobot relatif dari variabilitas inflasi, variabilitas kesenjangan output, dan penghalusan pergerakan suku bunga (interest rate smoothing).

Pemilihan $\lambda$ menentukan tingkat fleksibilitas (degree of flexibility) dalam penerapan IT dan berpengaruh pada stabilisasi output dan inflasi, dimana terdapat dalam policy objective (persamaan loss function). Kasus dimana $\lambda=0$ dikatakan strict IT, dimana tidak ada perhatian langsung pada variabilitas output. Sementara, kasus dimana kesenjangan output masuk ke dalam loss function $(\lambda>0)$, dikatakan flexible IT. Dalam prakteknya, stabilisasi output memegang peranan penting dalam IT.

Permasalahan bank sentral adalah memilih instrumen kebijakannya (suku bunga nominal), $i_{t}$, berdasarkan informasi-informasi yang ada pada periode $t$, yaitu dengan meminimasi (1) dengan subject to model makroekonomi.

Adapun struktur dasar dari model ekonomi terdiri dari beberapa persamaan inti, yaitu:

- IS curve atau persamaan agregate demand yang menggambarkan hubungan dinamis antara output riil, suku bunga riil, dan nilai tukar riil.

- $\quad$ LM Curve atau persamaan money demand yang menggambarkan demand for real money balance sebagai fungsi dari ukuran transaksi (biasanya real income) dan variabel opportunity cost (yaitu suku bunga nominal). Namun, biasanya persamaan ini jarang dipakai karena variabel real money balance tidak masuk baik dalam persamaan loss function maupun persamaan policy rule.

- Phillips curve atau persamaan aggregat supply yang menggambarkan respon dinamis dari kesenjangan output terhadap inflasi. 
- Uncovered interest rate parity (UIP) atau persamaan nilai tukar yang menggambarkan hubungan antara nilai tukar dengan spread antara suku bunga (nominal atau riil) dalam negeri dan luar negeri.

Merujuk pada Small Scale Economic Macroeconomics Model Bank of England, persamaan-persamaan di atas dapat digambarkan sebagai berikut:

$$
\begin{array}{lll}
\text { - Aggregat demand } & : & \mathrm{y}_{\mathrm{t}}=\beta_{y} B(L)\left(y_{t}\right)-\beta_{r} r_{t}+\beta_{d} \Delta q_{t}+\varepsilon_{y t} \\
- \text { Philips curve } & : & \pi_{t}=\alpha_{\pi} B(L) \pi_{t}+\alpha_{y} B(L)\left(y_{t}-y_{t}^{*}\right)+\alpha_{m} P_{t}^{m}+\varepsilon_{\pi_{t}} \\
- \text { Import price } & : & P_{t}^{m}=\alpha_{m} B(L) P_{t}^{m}+\beta_{q} B(L) q_{t}+\beta_{t} B(L) \Delta q_{t}+\varepsilon_{m t} \\
\text { - Exchange rate } & : & \Delta q_{t}=\Delta i_{t}^{f}-\Delta i_{t}^{t}+\beta_{t} B(L) \Delta q_{t}+R P_{t}+\varepsilon_{q_{t}} \\
- \text { Risk premium } & : & R P_{t}=\beta_{t} B(L) \Delta q_{t}+F L_{t}^{*}+\varepsilon_{r_{t}}
\end{array}
$$

\section{Dimana:}

$$
\begin{array}{ll}
\beta, \alpha & =\text { koefisien parameter } \\
\mathrm{B}(\mathrm{L}) & =\text { lag operator } \\
\mathrm{y}_{\mathrm{t}} & =\text { PDB riil } \\
\mathrm{y}_{\mathrm{t}}{ }^{*} & =\text { PDB Potensial } \\
\mathrm{r}_{\mathrm{t}} & =\text { suku bunga riil } \\
\mathrm{q}_{\mathrm{t}} & =\text { nilai tukar rupiah } \\
\pi_{\mathrm{t}} & =\text { inflasi } \\
\mathrm{P}_{\mathrm{t}} & =\text { harga impor } \\
\mathrm{i}_{\mathrm{t}}^{\mathrm{f}} & =\text { suku bunga nominal luar negeri } \\
\mathrm{i}_{\mathrm{t}}^{\mathrm{d}} & =\text { suku bunga nominal luar negeri } \\
\mathrm{RP}_{\mathrm{t}} & =\text { risk premium } \\
\mathrm{FL}_{\mathrm{t}} & =\text { hutang luar negeri }
\end{array}
$$

Karena Loss Function yang berbentuk kuadratik diminimasi dengan subject to model yang berbentuk linear, maka hasil solusinya adalah berupa optimal policy rule yang berbentuk linear.

Sementara itu pada metode yang kedua, simulasi stochastic, policy rule diperoleh dengan melakukan simulasi pada model makro ekonomi dengan membangkitkan bilangan random berulang kali. Bilangan random tersebut dapat dianggap sebagai shock-shock yang terjadi di suatu persamaan, misalnya demand shocks, exchange rate shocks, dan supply shocks, karena 
karakteristik bilangan random tersebut (mean dan variance) dibuat sama/mirip dengan karakteristik error-error yang ada pada model. Dengan memberikan variasi pembobotan (weight) pada inflasi dan/atau kesenjangan output, maka parameter policy rule diperoleh dengan memperhitungkan variabilitas inflasi dan variabilitas kesenjangan output.

Pada metode simulasi ini, persamaan loss function tidak secara eksplisit dimasukkan ke dalam model, akan tetapi persamaan struktur dasar ditutup dengan persamaan policy rule. Persamaan policy rule ditentukan dengan memberikan koefisien yang dapat diubahubah besarannya.

Terdapat 3 (tiga) bentuk umum policy rule yang diteliti, yaitu :

$$
\begin{aligned}
& \mathrm{i}_{\mathrm{t}}=\gamma \mathrm{i}_{\mathrm{t}-1}+\theta\left[\pi_{\mathrm{t}}^{\mathrm{e}}-\pi^{*}\right]+\left(1-\theta_{\mathrm{i}}\right)\left[\mathrm{Y}_{\mathrm{t}}-\mathrm{Y}^{*}\right] \\
& \mathrm{i}_{\mathrm{t}}=\gamma \mathrm{i}_{\mathrm{t}-1}+\theta\left[\pi_{\mathrm{t}+\mathrm{i}}^{\mathrm{e}}-\pi^{*}\right] \\
& \mathrm{i}_{\mathrm{t}}=\gamma \mathrm{i}_{\mathrm{t}-1}+\theta\left[\pi_{\mathrm{t}+\mathrm{i}}^{\mathrm{e}}-\pi^{*}\right]+\left(1-\theta_{\mathrm{i}}\right)\left[\mathrm{Y}_{\mathrm{t}}-\mathrm{Y}^{*}\right]
\end{aligned}
$$

dimana i adalah suku bunga nominal jangka pendek sebagai instrumen kebijakan, $\pi^{*}$ adalah target inflasi, $\pi^{\mathrm{e}}$ adalah inflasi aktual atau proyeksi inflasi, $\mathrm{Y}$ adalah output riil aktual dan $\mathrm{Y}^{*}$ adalah output potential. Jumlah leads, $j$, adalah time horizon untuk mencapai target, $\gamma$ adalah parameter penghalusan suku bunga, dan $\theta$ adalah parameter umpan balik kebijakan. Persamaan (7) sering disebut Taylor Rule, persamaan (8) disebut Inflation Forcaste Based Rule (IFB Rule), sedangkan persamaan (9) disebut Inflation Forecast Based Rule with Contemporaneous Output Gap (IFB-OG).

Setelah dilakukan simulasi dengan menggunakan bobot yang berbeda-beda, maka akan diperoleh suatu grafik conveksitas trade-off antara variabilitas inflasi dengan variabilitas output (atau kesenjangan output) seperti yang terlihat pada gambar 1. Pada gambar tersebut

\section{Gambar 1. Variabilitas Inflasi dan Output}

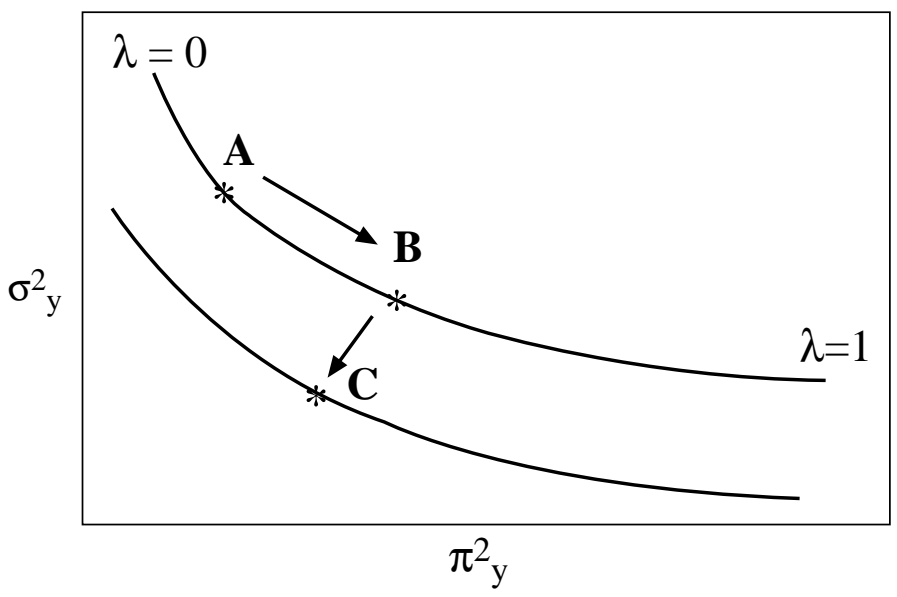


terlihat bahwa semakin besar bobot pada stabilisasi output, maka semakin kecil variabilitas output, tetapi variabilitas inflasi akan semakin besar. Begitu pula sebaliknya. Bank Sentral harus memilih besaran 1 yang mengoptimalkan variabilitas inflasi dan variabilitas output.

Pemilihan variabilitas yang optimal pada frontier kurva akan berpengaruh pada kecepatan bank sentral dalam memperoleh kredibilitas. Pada saat variabilitas optimum ditentukan pada titik A, dimana bank sentral lebih concern dengan variabilitas inflasi yang rendah, bank sentral akan mendapatkan kredibilitas terlebih dahulu (lebih dini) dalam memerangi inflasi ketimbang mengurangi variabilitas output (titik B). Pada saat kredibilitas sudah terbentuk dan cenderung membaik, bank sentral dapat menerapkan kebijakan yang lebih fleksible pada titik B, atau secara potensial dapat berada pada titik C dimana frontier lebih dekat ke titik origin.

Batini \& Haldane (1998) menganggap bahwa IFB rules sebagai simple monetary rule dan mempunyai beberapa keuntungan. Pertama, rule ini analog dengan spesifikasi rule lainnya, termasuk Taylor Rule. Kedua, model sederhana akan lebih baik jika terdapat ketidakpastian (uncertainty) dalam struktur real ekonomi. Ketiga, dengan rule yang sederhana akan membantu bank sentral dalam membangun kredibilitasnya dan dapat meningkatkan kemampuan monitoring oleh stake-holders.

Sementara itu Drew \& Hunt (1999) berpendapat bahwa dengan memberikan bobot yang positif pada stabilisasi output dalam fungsi reaksi kebijakan bank sentral, maka inflasi akan lebih baik dibandingkan apabila hanya merespon inflasi, mengingat output pada saat ini menentukan inflasi mendatang.

\section{Metodologi}

Metodologi yang digunakan dalam makalah ini adalah dengan menggunakan metode simulasi stochastic. Dengan metode simulasi ini, shocks dibangkitkan secara random, lalu dimasukkan ke dalam model yang ditutup dengan persamaan policy rule. Shock-shock yang "ditembakkan" ke dalam model selanjutnya di-run ulang dengan berbagai kombinasi bobot inflasi dan bobot kesenjangan output, serta kombinasi time horizon perkiraan inflasi yang akan direspon.

Jenis shocks yang digunakan adalah:

1. Shocks nilai tukar (exchange rate shocks) yang mengikuti AR(1) process.

2. Stochastic disturbance shocks yang terdiri dari demand shocks dan supply shocks. Nilai awal dari shock-shock ini diperoleh dari residual model tersebut.

3. Model uncertainty shocks yang juga terdiri dari demand dan supply shocks. Shocks-shocks 
tersebut diperoleh dari suatu generic small scale macro model yang selanjutnya ditambahkan ke dalam "the true model".

Persamaan policy rule yang digunakan adalah sebanyak 3 bentuk, yaitu Taylor Rule, IFB, dan IFB-OG dimana hasil dari masing-masing policy rule tersebut diplot ke dalam grafik trade-off antara variabilitas inflasi dan variabilitas kesenjangan output. Setelah di-run untuk beberapa replikasi, maka akan terlihat frontier yang paling optimum (close to the origin) dan selanjutnya dipilih sebagai policy rule. Adapun alur metodologi secara lengkap dapat dilihat pada lampiran.

\section{Model}

Model smallscale macroeconomic (SSMM) Bank Indonesia beberapa persamaan inti seperti terlihat pada gambar 2 .

\section{Gambar 2. Mekanisme Kerja Model Simultan}

\section{Mekanisme KerjaModel Simultan}

Dalam Rangka Penentuan Policy Rules

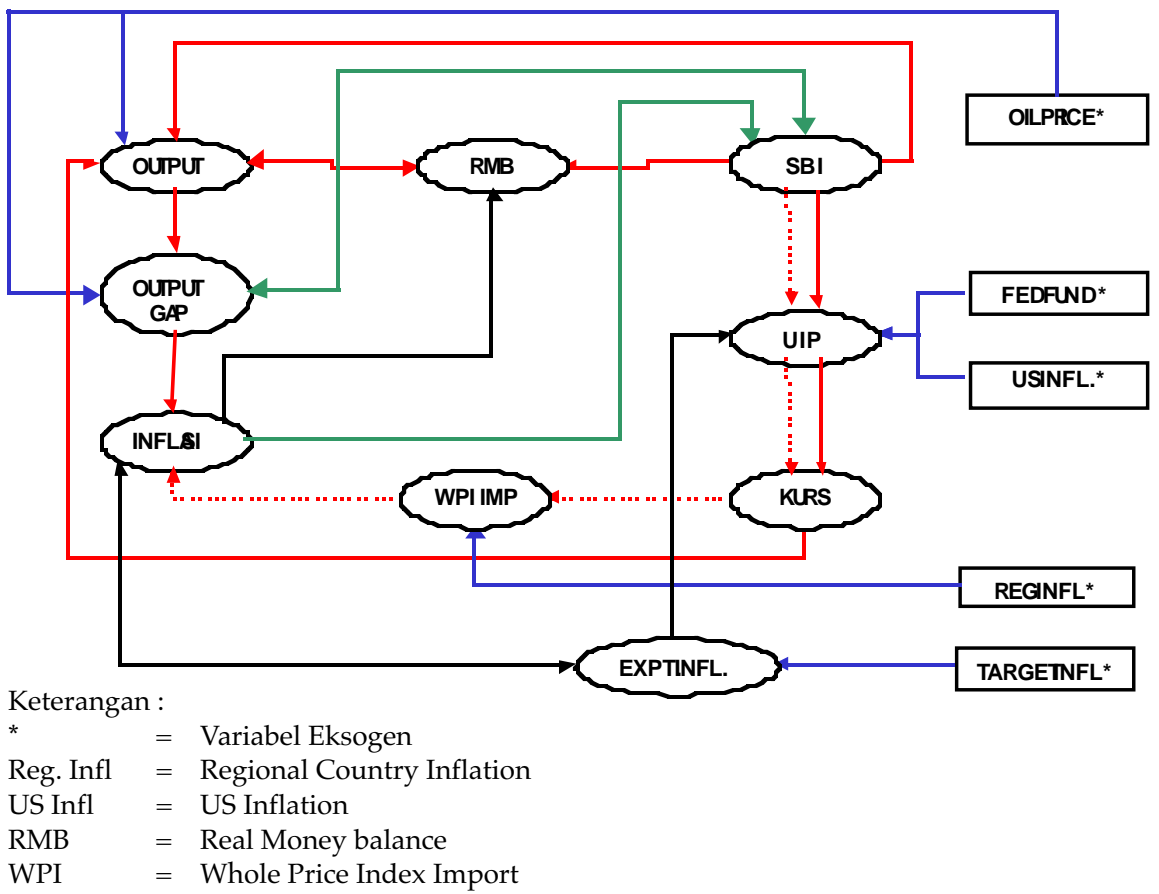

Model yang digunakan adalah model kuartalan yang terdiri dari beberapa persamaan, yaitu (a) output gap, (b) aggregate demand, (c) real money balance, (d) Phillips curve, (e) import 
price, dan (f) exchange rate. Sistem persamaan dinamis di atas selanjutnya ditutup dengan persamaan policy rule.

Persamaan kesenjangan output dibentuk sebagai fungsi dari pertumbuhan ekonomi, suku bunga jangka pendek, dan harga minyak.

$$
Y-Y^{*}=\alpha 1+\alpha 2 \Delta Y-\alpha 3 i_{t}+\alpha 4 o_{t-3}+\alpha 5 \text { seasonal_fac. }
$$

Pada saat output riil melebihi potensialnya tekanan permintaan agregat akan meningkat, kesenjangan output menjadi positif. Tekanan permintaan juga dipengaruhi secara langsung oleh konsumsi yang tinggi dimana tercermin dari efek substitusi dalam suku bunga jangka pendek. Selanjutnya, perubahan pada harga minyak dunia mempengaruhi pendapatan pemerintah dalam negeri, terutama pada hasil ekspornya, yang pada gilirannya meningkatkan PDB.

Permintaan agregat mengikuti pesamaan di bawah ini dengan suku bunga jangka pendek, nilai tukar, real money balance dan harga minyak sebagai explantory variables:

$$
\Delta Y=\alpha 5+\alpha 6 \Delta Y_{t-1}-\alpha 7 i-\alpha 8 e+\alpha 9 \Delta\left(m_{t}-p_{t}\right)+\alpha 10 o_{t}
$$

Efek yang negatif dari nilai tukar pada pertumbuhan GDP berkaitan erat dengan tingginya import content dari produksi dalam perekonomian Indonesia. Sebagai akibatnya, depresiasi nilai tukar rupiah akan mengurangi nilai tambah (value added) dari barang-barang yang diproduksi di dalam negeri, dan selanjutnya akan mengurangi pendapatan.

Persamaan real money balance merupakan fungsi dari income level, inflasi, dan interest rates (suku bunga jangka pendek SBI and suku bunga pinjaman investasi). Real money balance dipengaruhi secara negatif oleh suku bunga dan inflasi, dan dipengaruhi secara positif oleh income level.

$$
m_{t}-p_{t}=\alpha 11+\alpha 12 m_{t-1}-p_{t-1}+\alpha 13 Y_{t}-\alpha 14 \Delta p_{t}-\alpha 15 \Delta i_{t}
$$

Sebagai gambaran dari adanya tekanan inflasi dalam suatu ekonomi yang tumbuh lebih tinggi, persamaan Philips curve berikut menggambarkan trade off antara output dan inflasi.

$$
\Delta p=\alpha 17+\alpha 18 \Delta p_{t-1}+(1-\alpha 18) \Delta p^{*}+\alpha 19 Y_{t}-Y^{*}{ }_{t}+\alpha 20 \Delta w p i
$$

Selain pengaruh dari agregat demand pada harga-harga (inflasi), persamaan ini juga melibatkan adanya tekanan dari sisi penawaran pada inflasi yang diwakilkan oleh indeks harga perdagangan besar. Tekanan ini sangat dipengaruhi oleh depresiasi atau apresiasi nilai tukar rupiah dan laju inflasi di sejumlah negara penyumbang terbesar volume impor Indonesia.

$$
\Delta w p i=\alpha 21+\alpha 22 e+\alpha 23 \Delta p^{\prime}
$$


Persamaan nilai tukar sederhana di bawah ini menggambarkan dinamisasi nilai tukar yang dijelaskan oleh perbedaan suku bunga (interest rate differentials) dan dummy variable yang menjelaskan variable-variabel lain yang tidak dipengaruhi secara langsung oleh bank sentral.

$$
e=\alpha 28+\alpha 29 \text { dummy }-\alpha 30 \text { id }
$$

Sistem simultan di atas kemudian ditutup dengan persamaan policy rule IFB-OG (inflation forecast based rule with contamporenous output gap) yang mana otoritas moneter dapat mengendalikan inflasi. Dengan memberikan beberapa alternatif bobot pada inflasi dan kesenjangan output, maka policy rule yang digunakan dapat berupa Taylor rule, IFB rule, dan IFB-OG rule.

$$
i=\alpha 24+\alpha 25 i_{t-1}+\alpha 26\left(\Delta p-\Delta p^{*}\right)+\alpha 27\left(Y-Y^{*}\right)
$$

Solusi persaman-persamaan di atas secara simultan menghasilkan besaran koefisienkoefisien sebagai berikut :

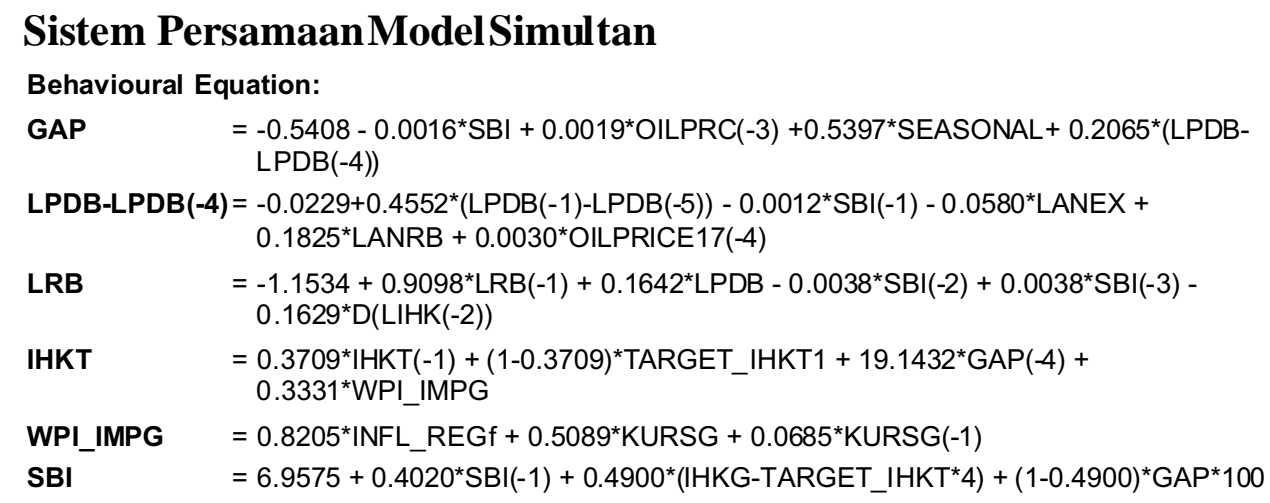

\section{Identity Equation:}

ID $=\left(\right.$ SBI- $\left(0.75^{\star} I H K H^{*} 4+\left(025^{*}\right.\right.$ TARGET_IHKT1 (4)*4) $)-($ US_I-US_INFL(4)))

D(LKURS) $=0.0107+0.8605^{*}$ DUMMY_NT1 - 0.0009*ID

KURS RP $=2.71828182845905^{\wedge}$ LKURS

KURSG $=$ KURS_RP/KURS_RP(-1)*100-100

LANEX=LKURS-LKURS(-4)

$\operatorname{LANRB}=\mathrm{LRB}-\mathrm{LRB}(-4)$

$\mathrm{LIHK}=\mathrm{LOG}(\mathrm{IHK})$

$\mathrm{IHK}=(100+\mathrm{HHKT}) / 100^{*} \mathrm{IHK}(-1)$

IHKT $=I H K / I H K(-1)^{*} 100-100$

IHKG $=I H K / I H K(-4)^{*} 100-100$

\section{Hasil Simulasi}

Hasil simulasi, sebagaimana terlihat pada gambar 3, menunjukkan bahwa dengan menambahkan unsur ketidakpastian yang berasal dari adanya shocks stokastik nilai tukar, permintaan dan penawaran ke dalam model, akan diperoleh variabilitas inflasi yang lebih tinggi relatif terhadap variabilitas kesenjangan output. Hal itu ditunjukkan oleh pergeseran 
kelompok kurva frontier dari kasus simulasi deterministik di dekat titik origin menuju kelompok kurva frontier untuk kondisi ketidakpastian nilai tukar yang jaraknya lebih jauh dari titik nol. Selanjutnya, penambahan shocks yang berasal dari model lain semakin menggeser kelompok kurva frontier ke sebelah kanan atas. Pergesaran kurva tersebut menggambarkan pengaruh ketidakpastian jalur transmisi kebijakan yang direpresentasikan oleh SSMM. Hal itu mengandung arti bahwa dengan adanya ketidakpastian transmisi kebijakan moneter, para pembuat kebijakan akan berada dalam perekonomian yang semakin volatile.

Gambar 3. Pergerakan kurva frontier pada berbagai jenis simulasi

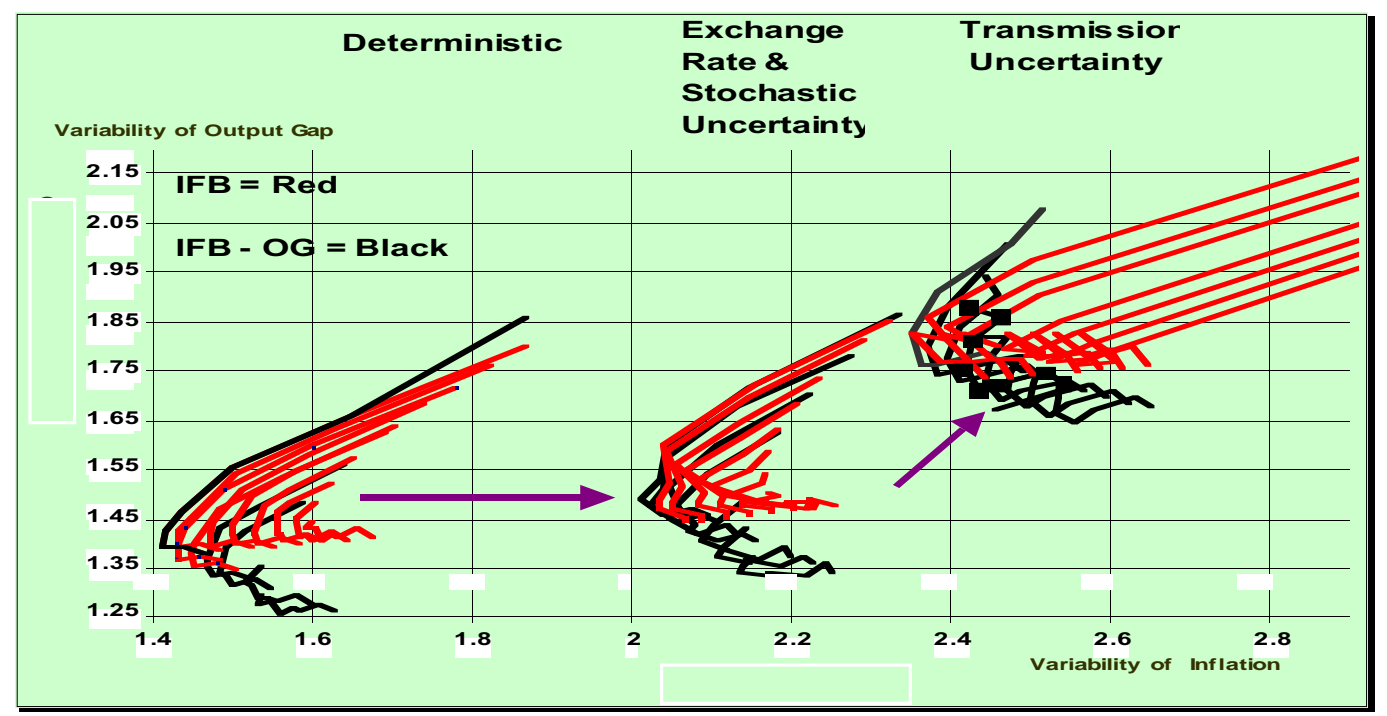

Gambar 3 tersebut mengindikasikan bahwa IFB-OG rule lebih robust dibandingkan IFB rule sederhana. Pada ketiga kasus, baik kasus deterministik, ketidakpastian nilai tukar, permintaan dan penawaran, serta ketidakpastian transmisi kebijakan, IFB-OG rule memungkinan penurunan variabilitas kesenjangan output dengan variabilitas inflasi yang lebih rendah dibandingkan jika menggunakan IFB rule.

Secara lebih khusus, simulasi determinisitik dan stokastik keluar dengan perkiraan bobot optimal sebesar 0,88 yang harus diberikan terhadap deviasi perkiraan inflasi dari targetnya (Gambar 4 dan 5). Bobot ini merupakan parameter umpan balik bagi kebijakan moneter untuk menstabilkan pergerakan laju inflasi menuju target yang dinginkan. Dengan demikian, simulasi tersebut merekomendasikan penggunaan bobot yang lebih rendah, yaitu 0,12, bagi stabilisasi kesenjangan output. Sementara itu, hasil simulasi sebagaimana tersaji pada gambar tersebut mengindikasikan bahwa kebijakan yang robust dicapai dalam horison 
Gambar 4. Hasil simulasi deterministik IFB dan IFB-OG rule

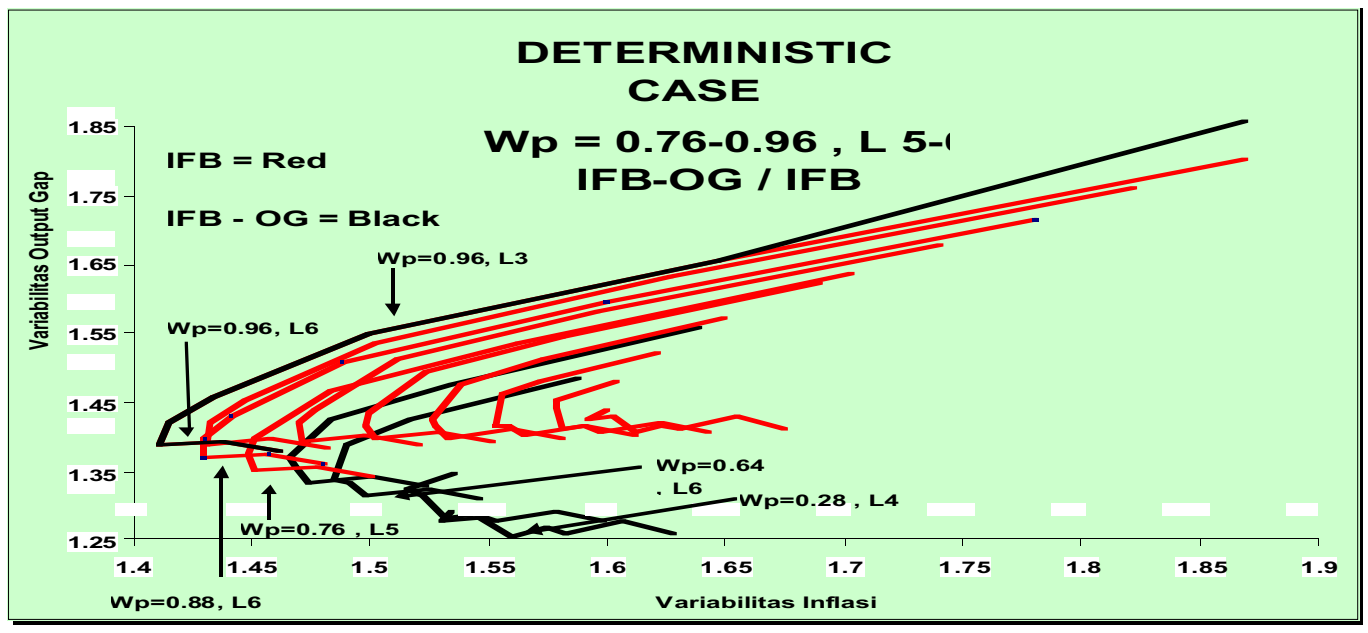

Gambar 5. Hasil Simulasi Stokastik

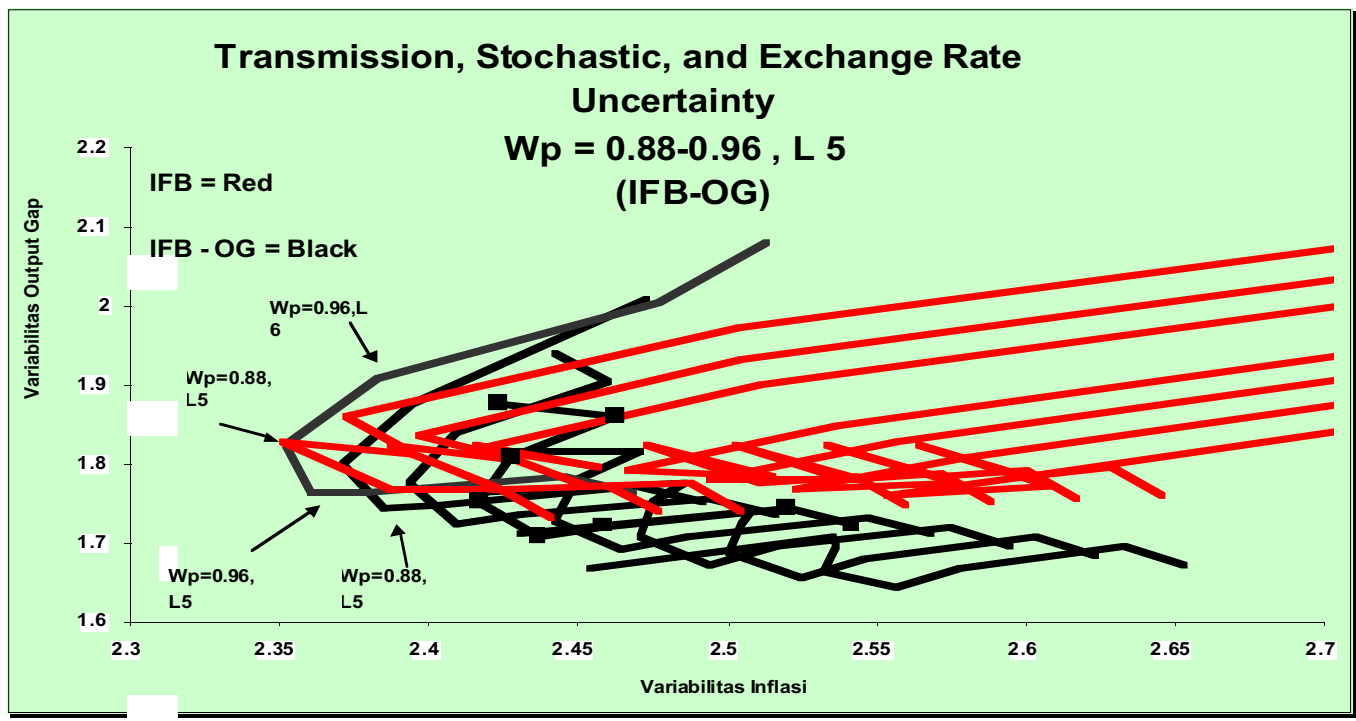

5 triwulan ke depan. Bobot untuk variabilitas output dan horizon kebijakan tersebut menggambakan derajat fleksibilitas yang optimal dalam penerapan policy rule di Indonesia. Oleh karena itu, penerapan kombinasi bobot dan horison kebijakan dalam model SSSM Bank Indonesia, akan menghasilkan path suku bunga yang robust yang akan mengarahkan pergerakan inflasi berada dalam rentang sasaran yang diinginkan. 


\section{Implikasi Kebijakan}

Berdasarkan hasil simulasi, IFB-OG rule digunakan sebagai fungsi reaksi kebijakan dalam model SSMM Bank Indonesia dimana parameter feedback dan horizon kebijakan dikalibrasi berdasarkan hasil simulasi stokastik. Selanjutnya, dilakukan simulasi kebijakan untuk menghasilkan path suku bunga yang akan mengendalikan pergerakan inflasi menuju

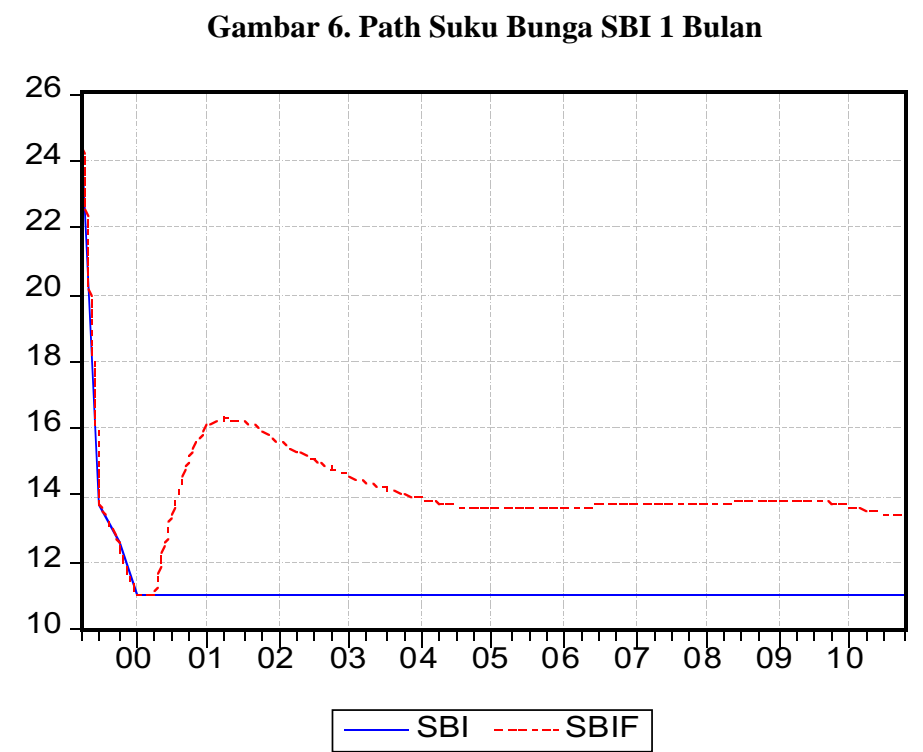

Gambar 7. Path Sasaran Inflasi dengan dan tanpa Policy Rule

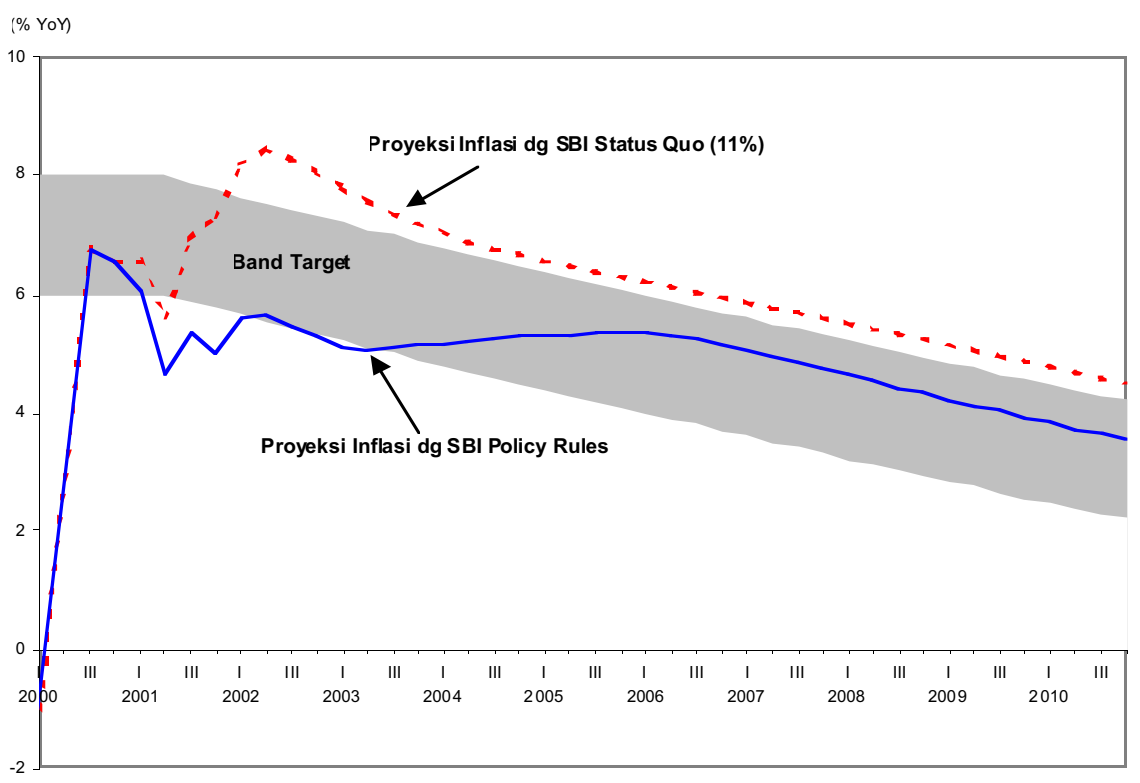


path sasaran yang optimal. Hasilnya, sebagaimana tersaji pada gambar 6, suku bunga SBI 1 bulan perlu dinaikkan ke tingkat 16\% hingga triwulan pertama tahun 2001 untuk selanjutnya turun dan stabil pada kisaran 13,5\% hingga 14\%. Dengan path seperti itu, inflasi diharapkan dapat berada dalam kisaran path sasarannya hingga menuju sasaran akhir $3-5 \%$ dalam sepuluh tahun ke depan (Gambar 7). Namun demikian, penetapan rule di atas, seperti yang disarankan oleh Armour \& Cote (1999), tidak dapat dan seharusnya tidak dikuti secara mekanistik oleh pembuat kebijakan.

\section{$\underline{\text { Referensi }}$}

Amano, Robert, Don Coletti, and Tiff Maclem, "Monetary Rules When Economic Behaviour Changes", Bank of Canada, April 1999.

Armour, Jamie, and Agathe Cote, "Feedback Rules for Inflation Control: An Overview of Recent Literature", Bank of Canada Review, Winter 1999-2000.

Bank of England, "Economic Models at Bank of England", Chapter 4, Small Scale Macroeconomic Models", 1999

Barucha, Nargis and Cristopher Kent, "Inflation Targeting in a Small Open Economy", Reserve Bank of Australia, 1998.

Batini, N., and A.G. Haldane, "Forward Looking Rules for Monetary Policy:, Bank of England Working Paper no. 91, 1999.

Boediono, "Merenungkan Kembali Mekanisme Transmisi Moneter di Indonesia", Buletin Ekonomi Moneter dan Perbankan, Vol. 1 No.1, Bank Indonesia, Juli 1998.

Bogdanski, Joel, Alexandre Antonio Tombini, and Sergio Riberio da Costa Werlang, "Implementing Inflation Targeting in Brazil", Draft Version, 2000.

Drew, Aaron, and Benjamin Hunt, "Efficient Simple Policy Rules and The Implications of Potential Output Uncertainty", Reserve bank of New Zealand, August 1999.

Iljas, Achjar, “Transmission Mechanism of Monetary Policy in Indonesia”, BIS Special Meeting (1997) 


\section{LAMPIRAN}


Diagram Alir Simulasi Deterministik Monetary Policy Rule

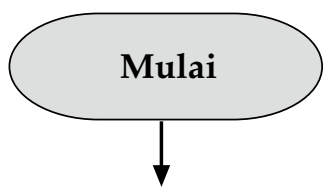

Mulai loop $\mathrm{k}=1$ s.d $\mathrm{n}$ ( $\mathrm{n}=$ \# jumlah kombinasi bobot inflasi dan bobot output gap pada persamaan policy rule)

Untuk tiap kombinasi bobot. Solve persamaan simultan untuk periode $\mathrm{t}+\mathrm{j}$ kuartal $(\mathrm{j}=1$ s.d 40) dgn alternatif monetary policy rule:

1) Taylor rule

2) IFB rules $t+j, j=1$ to 8

3) IFB-OG rules $t+j ; j=1$ to 8

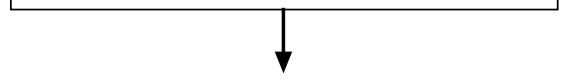

Untuk tiap kombinasi bobot: Hitung variance output gap, inflasi dan suku bunga SBI utk $\mathrm{t}+\mathrm{j} ; \mathrm{j}=1$ s.d 40 kuartal
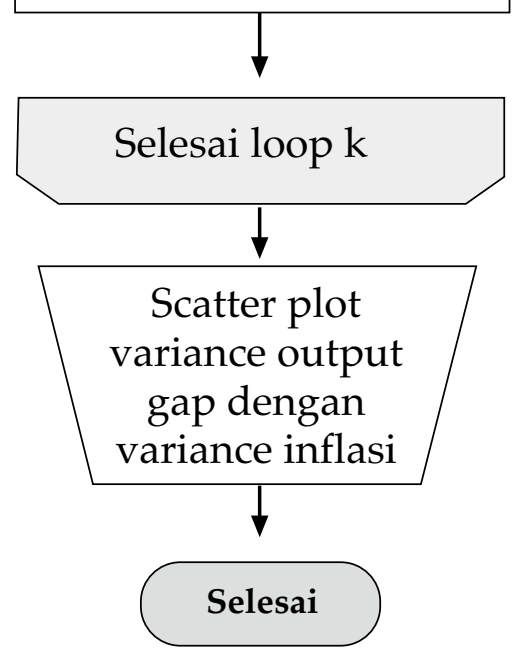


\section{Diagram Alir Simulasi Stokastik \\ Monetary Policy Rule}

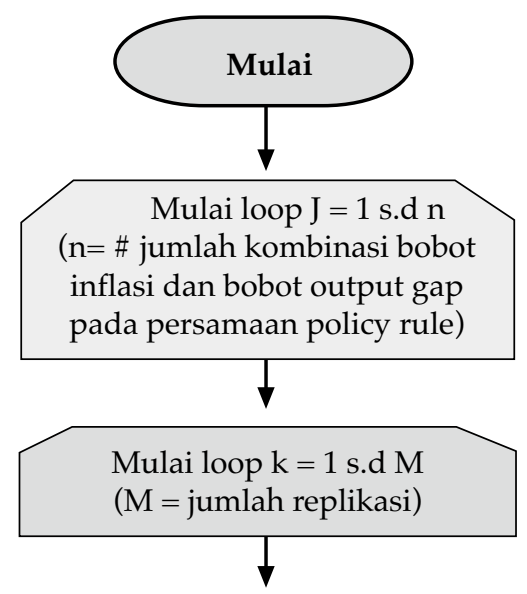

Bangkitkan random series 40

kuartal ke depan untuk:

1. Random shocks model utama
a. exchange rate shocks
b. supply shocks
c. demand shocks

2. Random shocks model alternatif (model uncertainty)

a. supply shocks

b. demand shocks
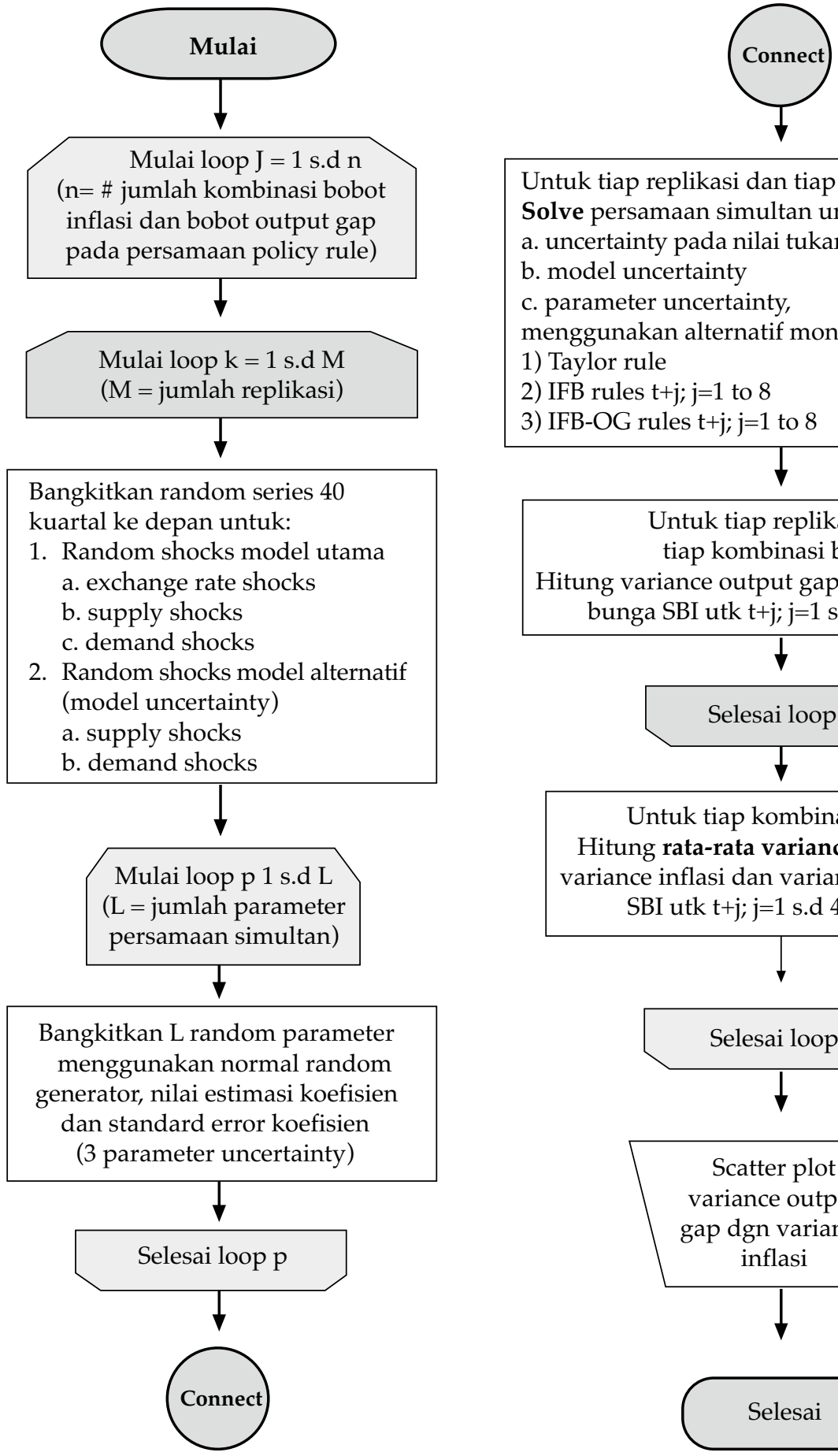

Untuk tiap replikasi dan tiap kombinasi bobot: Solve persamaan simultan untuk kasus:

a. uncertainty pada nilai tukar, output dan inflasi

b. model uncertainty

c. parameter uncertainty,

menggunakan alternatif monetary policy rule:

1) Taylor rule

2) IFB rules $t+j ; j=1$ to 8

3) IFB-OG rules $t+j ; j=1$ to 8

\section{Untuk tiap replikasi dan} tiap kombinasi bobot:

Hitung variance output gap, inflasi dan suku bunga SBI utk $\mathrm{t}+\mathrm{j} ; \mathrm{j}=1$ s.d 40 kuartal

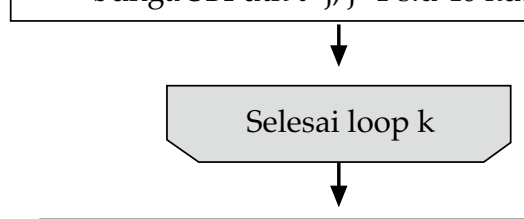

Untuk tiap kombinasi bobot:

Hitung rata-rata variance output gap, variance inflasi dan variance suku bunga

SBI utk $t+j ; j=1$ s.d 40 kuartal
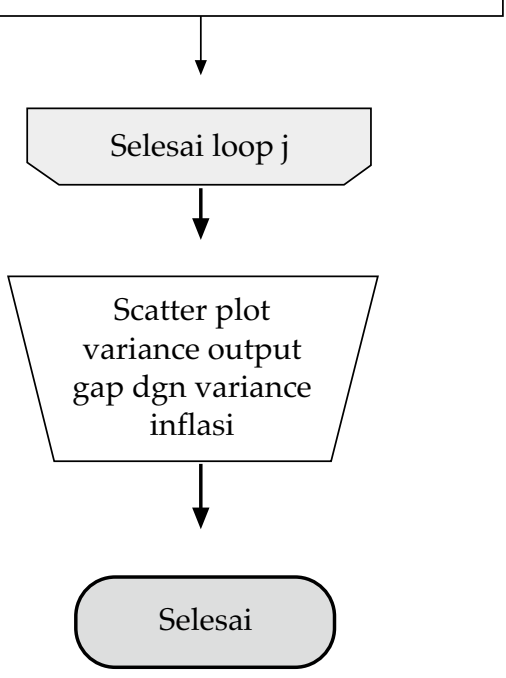


\section{Source Code Simulasi Policy Rule dengan IFB-OG Rule}

\section{‘ MONETARY POLICY RULE SIMULATION}

'Bank Indonesia

'Directorate of Economic Research and Monetary Policy

'Real Sector Studies Division

‘ Jakarta, July 2000

load ifbogfile include ifbogmodd include ifbogmods include ifbogmodfs

'initialisation

smpl 2000:1 2010:4

scalar $\mathrm{n}=10$

scalar m_ey $=0.005502$

scalar m_ep $=0.017382$

scalar m_eer $=0.006431$

scalar m_ds $=0.007183$

scalar m_ss $=-0.002655$

scalar m_ips $=0$

scalar $\mathrm{m} \_$ies $=0$

scalar m_bqss $=0.000165$

scalar m_bqds $=0.001155$

scalar s_ey $=0.028004$

scalar s_ep $=1.63947$

scalar s_eer $=0.024522$

scalar s_ds $=0.038444$

scalar s_ss $=0.045025$

scalar s_ips $=0$

scalar s_ies $=0$

scalar s_bqss $=0.029117$

scalar s_bqds $=0.051314$

scalar lamda $=0.5$

scalar discfactor $=0.99$

vector $(36) \mathrm{cm}$

vector(36) cf

vector(26) wp

vector(26) wy

matrix $(26,3)$ varia

for $! j=1$ to 26

$w p(! j)=-0.04+0.04^{*} ! j$

$w y(! j)=1-w p(! j)$

next

for $! q=1$ to $n$

vector(36) $\mathrm{cm}\{! q\}$ 


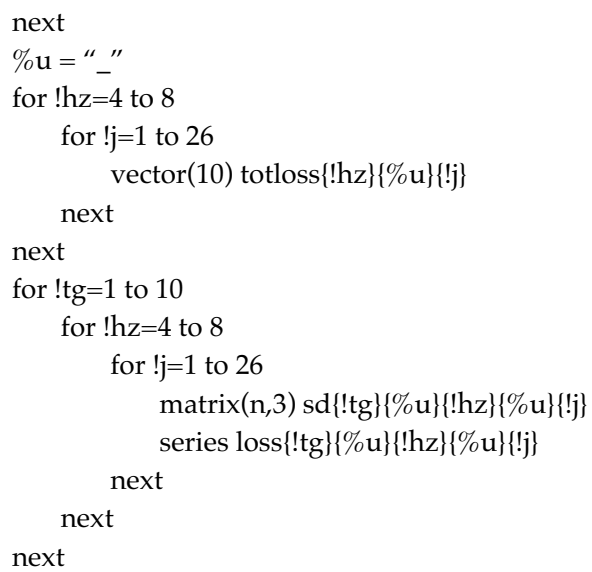

'(1). without error (deterministic simulation)

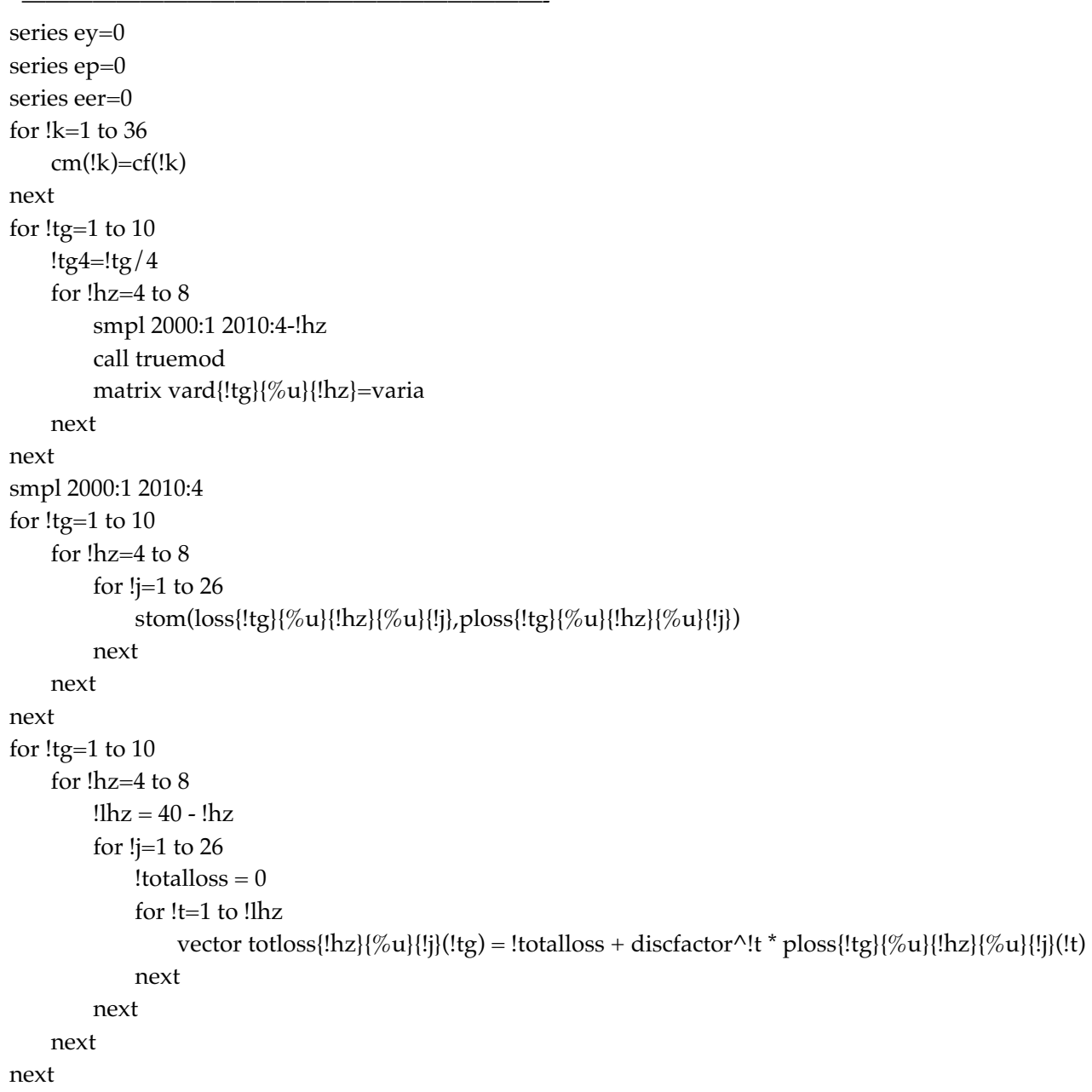


(2). Stochastic simulation : (1) plus exchange rate shocks

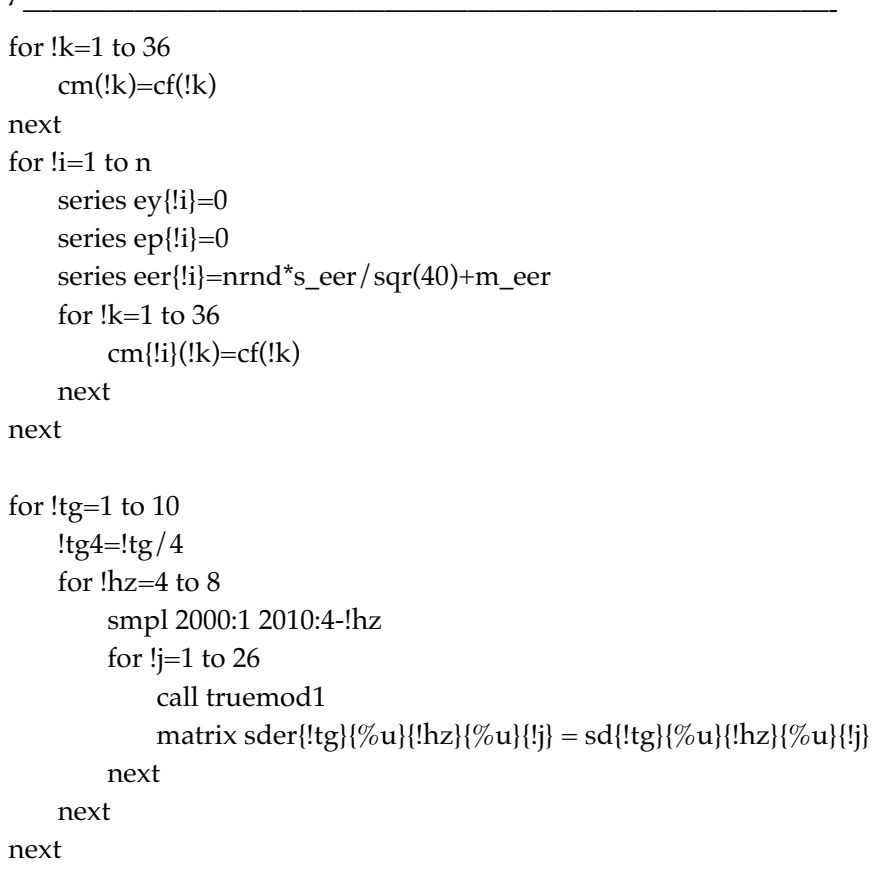

'(3). Stochastic simulation: (2) with generated residual shocks

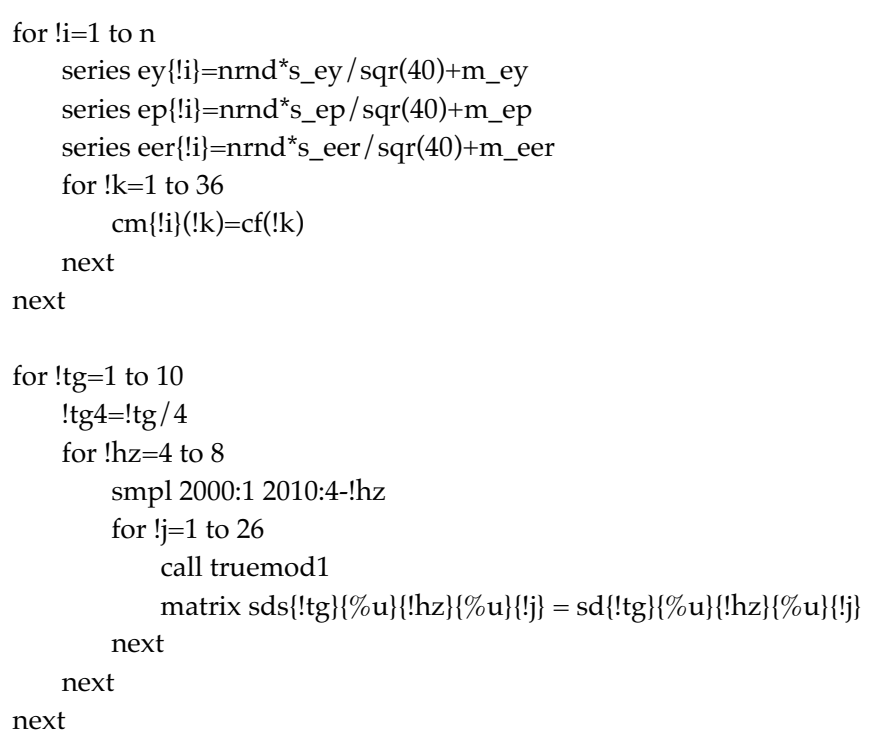

'(4). Stochastic simulation : (3) plus generated shocks from alternative model 


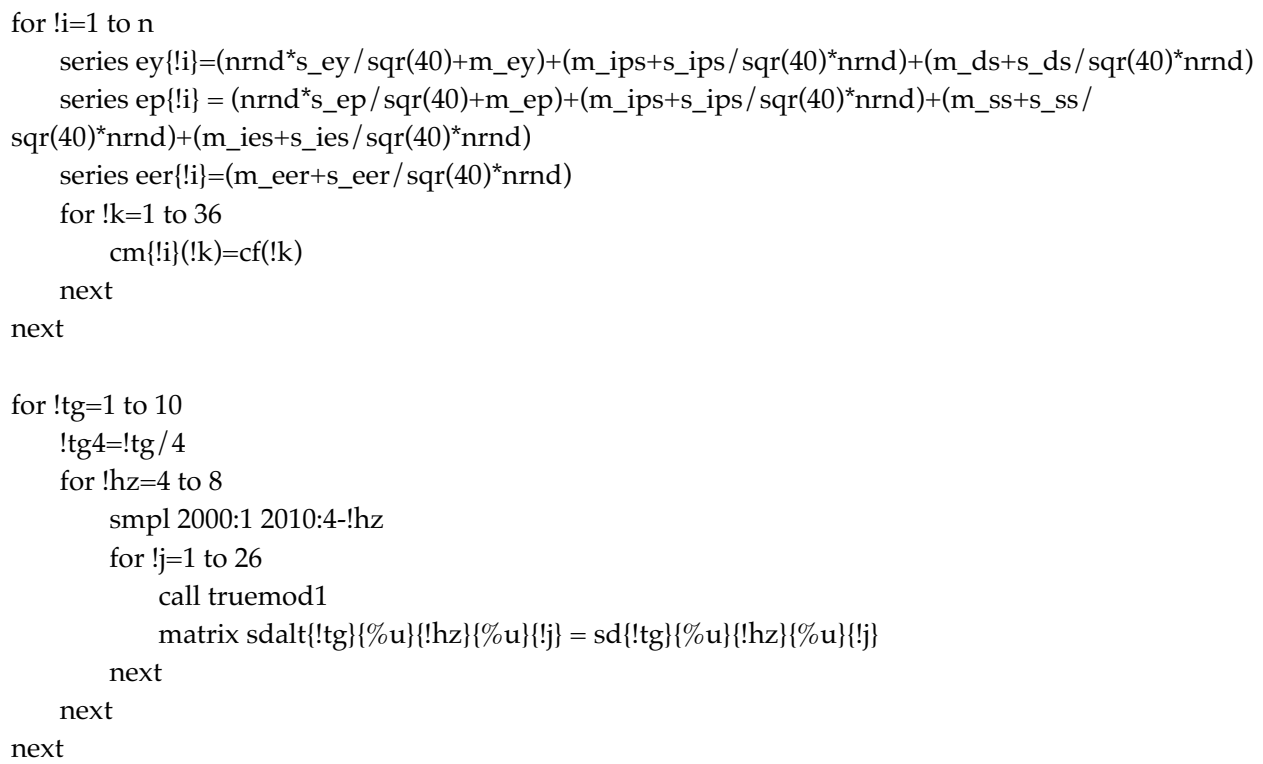

(6). Fully-stochastic simulation : (5) plus parameter uncertainty

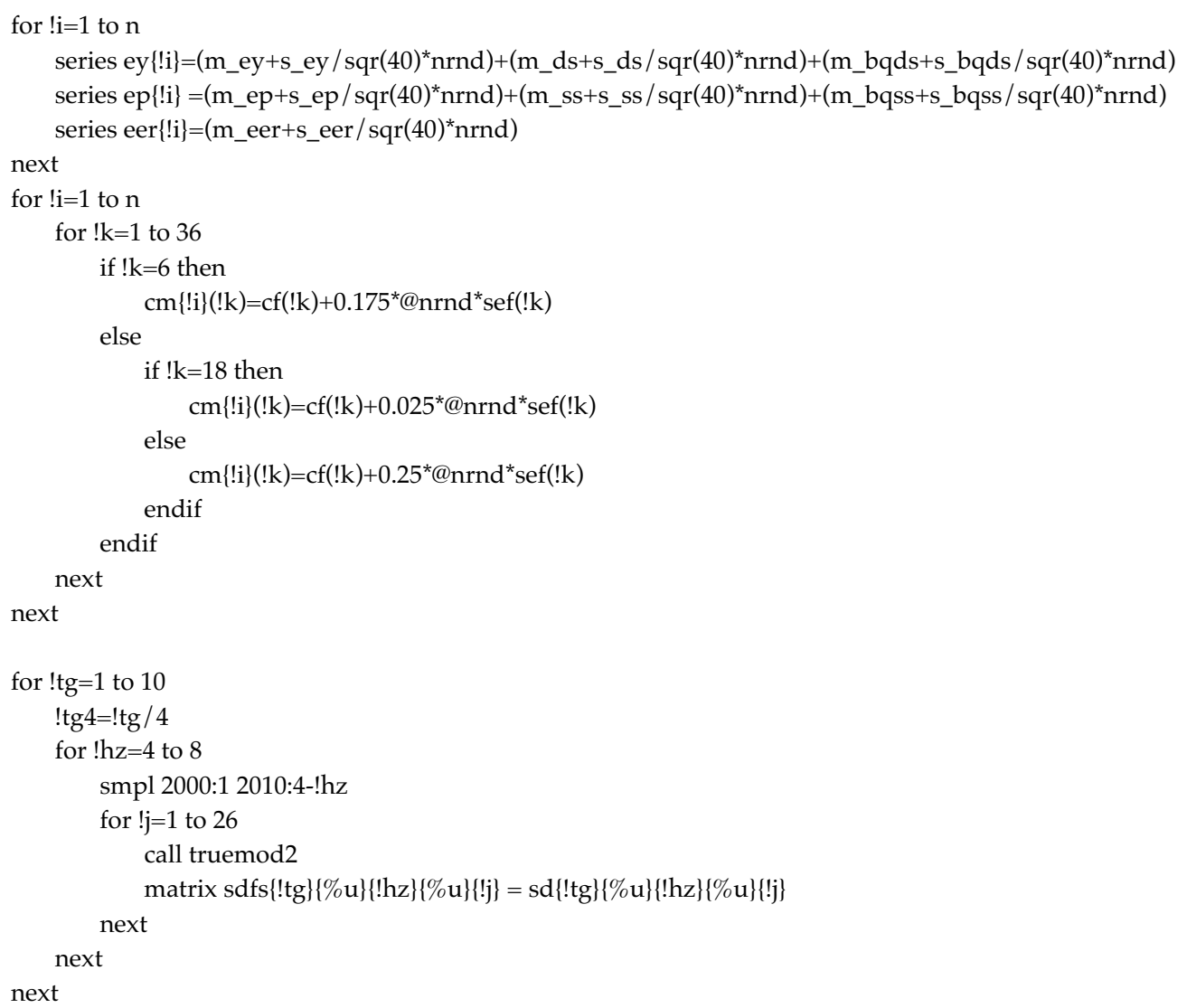


delete eer*
delete ep*
delete ey*
save ifbogfile
close ifbogfile

subroutine truemod

for $! j=1$ to 26

model true

true.add assign@all_F2

true.append gap $=\mathrm{cm}(1)+\mathrm{cm}(2)^{*} \mathrm{sbi}+\mathrm{cm}(3)^{*}$ oilprc $(-3)+\mathrm{cm}(4)^{*}$ seasonal $+\mathrm{cm}(5)^{\star}(1 \mathrm{pdb}-1 \mathrm{pdb}(-4))+\mathrm{ey}$

true.append $\operatorname{lpdb}-\operatorname{lpdb}(-4)=\mathrm{cm}(6)+\mathrm{cm}(7)^{*}(\operatorname{lgov}(-1)-\operatorname{lgov}(-5))+\mathrm{cm}(8)^{*} \mathrm{sbi}(-1)+\mathrm{cm}(9)^{*} \operatorname{lanex}+\mathrm{cm}(10)^{\star} \operatorname{lanrb}(-$

1) $+\mathrm{cm}(11)^{*}$ oilprice17(-3)

true.append $\operatorname{lrb}=\mathrm{cm}(12)+\mathrm{cm}(13)^{\star} \operatorname{lrb}(-1)+\mathrm{cm}(14)^{\star} \operatorname{lpdb}(-1)+\mathrm{cm}(15)^{\star} \mathrm{d}(\mathrm{lihk}(-2))+\mathrm{cm}(16)^{*} \mathrm{sbi}(-1)+\mathrm{cm}(17)^{\star} \mathrm{sbi}(-2)$

true.append linv $=\mathrm{cm}(18)+\mathrm{cm}(19)^{*} \operatorname{linv}(-1)+\mathrm{cm}(20)^{*} \operatorname{lpdb}+\mathrm{cm}(21)^{\star} \mathrm{lt} \_\mathrm{r}(-2)$

true.append ihkt $=\mathrm{cm}(22)^{*}$ ihkt $(-1)+(1-\mathrm{cm}(22))^{*} ! \operatorname{tg} 4+\mathrm{cm}(23)^{*} \mathrm{gap}(-4)^{*} 100+\mathrm{cm}(24)^{*}$ wpi_impg+ep

true.append wpi_impg $=\mathrm{cm}(25)+\mathrm{cm}(26)^{*} \mathrm{kursg}+\mathrm{cm}(27)^{\star} \mathrm{kursg}(-1)$

true.append lt_r $=\mathrm{cm}(28)+\mathrm{cm}(29)^{*} \mathrm{lt} \_\mathrm{r}(-1)+\mathrm{cm}(30)^{*} \mathrm{sbi}$

true.append $\mathrm{sbi}=\mathrm{cm}(31)+\mathrm{cm}(32)^{*} \operatorname{sbi}(-1)+w p(! j)^{*}(\mathrm{ihkgf}(! \mathrm{hz})-! \operatorname{tg})+w y(! j)^{*}$ gapf $f^{*} 100$

true.append d(lkurs) $=\mathrm{cm}(34)+\mathrm{cm}(35)^{*}$ dummy_nt $1+\mathrm{cm}(36)^{*} \mathrm{id}+$ eer

true.append kurs_rp $=2.71828182845905^{\wedge} \mathrm{lkurs}$

true.append kursg=kurs_rp/kurs_rp $(-1)^{*} 100-100$

true.append lanex=lkurs-lkurs(-4)

true.append id $=\left(\operatorname{sbi}-\left(0.75^{*}\right.\right.$ ihkt* $\left.4+0.25^{*} ! \operatorname{tg} 4\right)-($ us_i-us_infl( $\left.(4))\right)$

true.append lanrb=lrb-lrb(-4)

true.append $\mathrm{rb}=2.71828182845905^{\wedge} \mathrm{Lrb}$

true.append $\mathrm{rbg}=\mathrm{rb} / \mathrm{rb}(-4)^{\star} 100-100$

true.append lihk $=\log (\mathrm{ihk})$

true.append $\mathrm{ihk}=(100+\mathrm{ihkt}) / 100 * \mathrm{ihk}(-1)$

true.append $\mathrm{ihkt}=\mathrm{ihk} / \mathrm{ihk}(-1)^{\star} 100-100$

true.append ihkg=ihk/ihk $(-4)^{\star} 100-100$

true.append $\mathrm{pdb}=2.71828182845905^{\wedge} \mathrm{lpdb}$

true.append $\mathrm{pdbg}=\mathrm{pdb} / \mathrm{pdb}(-4)^{\star} 100-100$

true.append lcap $=\log ($ capital $)$

true.append capital $=$ capital $(-1)^{*} 0.98+$ inv

true.append inv $=2.71828182845905^{\wedge} \operatorname{linv}$

true.solve

varia $(! j, 1)=100 * @$ stdev $($ gap_f2 $)$

$\operatorname{varia}(! j, 2)=@ \operatorname{stdev}($ ihkt_f2 $)$

varia(!j,3)=@stdev(sbi_f2)

series loss $\{$ !tg $\}\{\% \mathrm{u}\}\{! \mathrm{hz}\}\{\% \mathrm{u}\}\{! \mathrm{j}\}=(\text { ihkgf-!tg })^{\wedge} 2+$ lamda $^{*}$ gapf^2

delete true

next

endsub

subroutine truemod1

for $! i=1$ to $n$

model truth

truth.add assign @all_F2

truth.append gap $=\mathrm{cm}(1)+\mathrm{cm}(2)^{\star} \mathrm{sbi}+\mathrm{cm}(3)^{\star}$ oilprc $(-3)+\mathrm{cm}(4)^{\star}$ seasonal $+\mathrm{cm}(5)^{\star}(\operatorname{lpdb}-\mathrm{lpdb}(-4))+\operatorname{ey}\{! \mathrm{i}\}$ 
truth.append lpdb-lpdb $(-4)=\mathrm{cm}(6)+\mathrm{cm}(7)^{*}(\operatorname{lgov}(-1)-\operatorname{lgov}(-5))+\mathrm{cm}(8)^{*} \operatorname{sbi}(-1)+\mathrm{cm}(9)^{*} \operatorname{lanex}+\mathrm{cm}(10)^{*} \operatorname{lanrb}(-$ 1) $+\mathrm{cm}(11)^{*}$ oilprice17(-3)

truth.append $\operatorname{lrb}=\mathrm{cm}(12)+\mathrm{cm}(13)^{*} \operatorname{lrb}(-1)+\mathrm{cm}(14)^{*} \operatorname{lpdb}(-1)+\mathrm{cm}(15)^{*} \mathrm{~d}(\operatorname{lihk}(-2))+\mathrm{cm}(16)^{*} \operatorname{sbi}(-1)+\mathrm{cm}(17)^{*} \mathrm{sbi}(-2)$

truth.append linv $=\mathrm{cm}(18)+\mathrm{cm}(19)^{*} \operatorname{linv}(-1)+\mathrm{cm}(20)^{*} \mathrm{lpdb}+\mathrm{cm}(21)^{*} \mathrm{lt} \_\mathrm{r}(-2)$

truth.append ihkt $=\mathrm{cm}(22)^{*}$ ihkt $(-1)+(1-\mathrm{cm}(22))^{*} ! \operatorname{tg} 4+\mathrm{cm}(23)^{*} \mathrm{gap}(-4)^{*} 100+\mathrm{cm}(24)^{*}$ wpi_impg + ep $\{1 \mathrm{i}\}$

truth.append wpi_impg $=\mathrm{cm}(25)+\mathrm{cm}(26)^{\star} \mathrm{kursg}+\mathrm{cm}(27)^{\star} \operatorname{kursg}(-1)$

truth.append lt_r $=\mathrm{cm}(28)+\mathrm{cm}(29)^{*} \mathrm{lt} \_\mathrm{r}(-1)+\mathrm{cm}(30)^{*} \mathrm{sbi}$

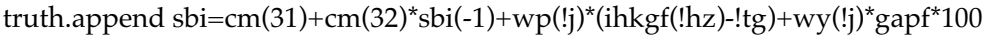

truth.append d(lkurs) $=\mathrm{cm}(34)+\mathrm{cm}(35)^{*}$ dummy_nt $1+\mathrm{cm}(36)^{*} \mathrm{id}+$ eer $\{\mathrm{i}\}$

truth.append kurs_rp $=2.71828182845905^{\wedge} \mathrm{lkurs}$

truth.append kursg=kurs_rp/kurs_rp $(-1)^{*} 100-100$

truth.append lanex=lkurs-lkurs(-4)

truth.append id $=\left(\right.$ sbi- $\left(0.75^{*}\right.$ ihkt $\left.{ }^{\star} 4+0.25^{\star} ! \operatorname{tg} 4\right)-($ us_i-us_infl( $\left.(4))\right)$

truth.append lanrb=lrb-lrb(-4)

truth.append $\mathrm{rb}=2.71828182845905^{\wedge} \mathrm{Lrb}$

truth.append $\mathrm{rbg}=\mathrm{rb} / \mathrm{rb}(-4)^{*} 100-100$

truth.append lihk $=\log (\mathrm{ihk})$

truth.append ihk $=(100+\mathrm{ihkt}) / 100 * \mathrm{ihk}(-1)$

truth.append ihkt=ihk/ihk $(-1)^{*} 100-100$

truth.append ihkg=ihk/ihk $(-4)^{*} 100-100$

truth.append $\mathrm{pdb}=2.71828182845905^{\wedge} \mathrm{lpdb}$

truth.append $\mathrm{pdbg}=\mathrm{pdb} / \mathrm{pdb}(-4)^{\star} 100-100$

truth.append lcap $=\log$ (capital)

truth.append capital=capital $(-1)^{\star} 0.98+$ inv

truth.append inv $=2.71828182845905^{\wedge} \mathrm{linv}$

truth.solve

sd $\{! \operatorname{tg}\}\{\%$ u $\}\{! h z\}\{\%$ u $\}\{! j\}(!$ i, 1$)=100 * @$ stdev(gap_f2)

$\operatorname{sd}\{! \operatorname{tg}\}\{\% \mathrm{u}\}\{! \mathrm{hz}\}\{\% \mathrm{u}\}\{! \mathrm{l}\}(! \mathrm{i}, 2)=@ \operatorname{stdev}($ ihkt_f2)

sd $\{! \operatorname{tg}\}\{\%$ u $\}\{! h z\}\{\%$ u $\}\{! j\}(! i, 3)=@$ stdev(sbi_f2)

delete truth

next

endsub

subroutine truemod2

for $! \mathrm{i}=1$ to $n$

model trust

trust.add assign @all_F2

trust.append gap $=\mathrm{cm}\left\{[\mathrm{i}\}(1)+\mathrm{cm}\{\mathrm{i}\}(2)^{*} \mathrm{sbi}+\mathrm{cm}\{\mathrm{li}\}(3)^{*}\right.$ oilprc $(-3)+\mathrm{cm}\{! \mathrm{i}\}(4)^{*}$ seasonal $+\mathrm{cm}\{\mathrm{i}\}(5)^{*}(1 \mathrm{pdb}-\mathrm{lpdb}(-$

4)) + ey $\{! \mathrm{i}\}$

trust.append lpdb-lpdb $(-4)=\mathrm{cm}\left\{[\mathrm{i}\}(6)+\mathrm{cm}\left\{[\mathrm{i}\}(7)^{*}(\operatorname{lgov}(-1)-\operatorname{lgov}(-5))+\mathrm{cm}\{! \mathrm{i}\}(8)^{*} \operatorname{sbi}(-\right.\right.$

$1)+\mathrm{cm}\left\{[\mathrm{i}\}(9)^{*} \operatorname{lanex}+\mathrm{cm}\left\{[\mathrm{i}\}(10)^{*} \operatorname{lanrb}(-1)+\mathrm{cm}\{! \mathrm{i}\}(11)^{*}\right.\right.$ oilprice $17(-3)$

trust.append $\operatorname{lrb}=\mathrm{cm}\{\mathrm{i}\}(12)+\mathrm{cm}\{\mathrm{li}\}(13)^{*} \operatorname{lrb}(-1)+\mathrm{cm}\{\mathrm{i}\}(14)^{*} \operatorname{lpdb}(-1)+\mathrm{cm}\{! \mathrm{l}\}(15)^{*} \mathrm{~d}(\mathrm{lihk}(-2))+\mathrm{cm}\{! \mathrm{i}\}(16)^{*} \mathrm{sbi}(-$

$1)+\mathrm{cm}\left\{[\mathrm{i}\}(17)^{*} \mathrm{sbi}(-2)\right.$

trust.append linv $=\mathrm{cm}\{\mathrm{i}\}(18)+\mathrm{cm}\{\mathrm{i}\}(19)^{*} \operatorname{linv}(-1)+\mathrm{cm}\{\mathrm{i}\}(20)^{*} \mathrm{lpdb}+\mathrm{cm}\{\mathrm{i}\}(21)^{*} \mathrm{lt} \_\mathrm{r}(-2)$

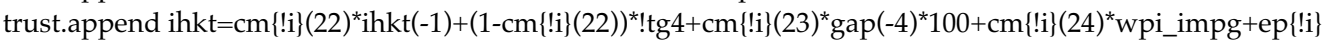

trust.append wpi_impg $=\mathrm{cm}\{! \mathrm{i}\}(25)+\mathrm{cm}\left\{[\mathrm{i}\}(26)^{*} \mathrm{kursg}+\mathrm{cm}\{! \mathrm{i}\}(27)^{*} \mathrm{kursg}(-1)\right.$

trust.append lt_r $=\mathrm{cm}\{! \mathrm{i}\}(28)+\mathrm{cm}\{! \mathrm{i}\}(29)^{*} \mathrm{lt} \_\mathrm{r}(-1)+\mathrm{cm}\{! \mathrm{i}\}(30)^{*} \mathrm{sbi}$

trust.append $\mathrm{sbi}=\mathrm{cm}\{! \mathrm{i}\}(31)+\mathrm{cm}\{! \mathrm{i}\}(32)^{*} \mathrm{sbi}(-1)+w p\left(! j^{*}(\mathrm{ihkgf}(! \mathrm{hz})-! \mathrm{tg})+w y(! \mathrm{j})^{*}\right.$ gapf ${ }^{*} 100$

trust.append d(lkurs) $=\mathrm{cm}\left\{[\mathrm{i}\}(34)+\mathrm{cm}\{\mathrm{i}\}(35)^{*}\right.$ dummy_nt $1+\mathrm{cm}\{! \mathrm{i}\}(36)^{*} \mathrm{id}+$ eer $\{\mathrm{i}\}$

trust.append kurs_rp $=2.71828182845905^{\wedge} \mathrm{lkurs}$

trust.append kursg=kurs_rp/kurs_rp $(-1)^{*} 100-100$

trust.append lanex=lkurs-lkurs(-4) 
trust.append id=(sbi- $\left(0.75^{*}\right.$ ihkt $\left.{ }^{*} 4+0.25^{*} ! \operatorname{tg} 4\right)-($ us_i-us_infl( $\left.(4))\right)$

trust.append lanrb=lrb-lrb(-4)

trust.append $\mathrm{rb}=2.71828182845905^{\wedge} \mathrm{lrb}$

trust.append $\mathrm{rbg}=\mathrm{rb} / \mathrm{rb}(-4)^{\star} 100-100$

trust.append lihk $=\log (\mathrm{ihk})$

trust.append $\mathrm{ihk}=(100+\mathrm{ihkt}) / 100 * \mathrm{ihk}(-1)$

trust.append ihkt=ihk/ihk $(-1)^{\star} 100-100$

trust.append ihkg=ihk/ihk $(-4)^{*} 100-100$

trust.append $\mathrm{pdb}=2.71828182845905^{\wedge} \mathrm{lpdb}$

trust.append $\mathrm{pdbg}=\mathrm{pdb} / \mathrm{pdb}(-4)^{\star} 100-100$

trust.append lcap $=\log$ (capital)

trust.append capital $=$ capital $(-1)^{*} 0.98+$ inv

trust.append inv $=2.71828182845905^{\wedge} \mathrm{linv}$

trust.solve

sd $\{! \operatorname{tg}\}\{\%$ u $\}\{! h z\}\{\%$ u $\}\{! j\}(! \mathrm{i}, 1)=100 * @$ stdev(gap_f2)

sd $\{! \operatorname{tg}\}\{\%$ u $\}\{! h z\}\{\%$ u $\}\{! j\}(! \mathrm{i}, 2)=@$ stdev(ihkt_f2)

sd $\{! \operatorname{tg}\}\{\%$ u $\}\{! h z\}\{\%$ u $\}\{! j\}(! i, 3)=@$ stdev(sbi_f2)

delete trust

next

endsub 